\title{
11. A Case of Hydatid Cyst Mimicking Superior Sulcus Tumor: Intrathoracic, Extrapulmonary, Intraosseous Location
}

\author{
Superior Sulkus Tümörünü Taklit Eden Kist Hidatik Olgusu: Intratorasik, \\ Ekstrapulmoner, Intraossöz Yerleşim
}

Fatih Meteroğlu, Atalay Şahin, Şevval Eren

\begin{abstract}
Hydatid cysts are rarely located outside of the liver and lungs. Exceptional locations, such as the intraosseous part of the rib can cause unusual symptoms. An accurate preoperative diagnosis is important, but may be confusing in some cases. The presented case here is an example of echinococcosis of the first rib in a young adult who complained of shoulder pain. Plain chest $x$-ray and computerized tomography scan were suggestive of a superior sulcus tumor. The lesion was resected and the histopathological examination confirmed hydatid disease.
\end{abstract}

Key words: Sulcus tumor, hydatid, cyst

\section{Özet}

Karaciğer ve akciğer dışında kist hidatik yerleşimi seyrektir. Kaburgaların kemik kısmı gibi nadir yerleşimler, alışık olmayan semptomlara yol açabilir. Cerrahi öncesi doğru tanı önemli olup bazı vakalarda şaşırtıcı olabilir. Omuz ağrısı çeken genç bir erişkin hastada görülen birinci kosta ekinokokoz olgusu sunuldu. Akciğer grafisinde ve toraks bilgisayarlı tomografisinde superior sulkus tümörü şüphesi vardı. Lezyon rezeke edildi ve histopatolojik inceleme sonucu kist hidatik tanısı kondu.

Anahtar Sözcükler: Sulkus tümör, hidatik, kist.

Correspondence (iletişim): Atalay Sahin, Dicle University, Medical School, Department of Thoracic Surgery, Diyarbakır, Turkey e-mail: atalaysahin44@yahoo.com 
Superior sulcus tumors are apically located bronchogenic malignancies involving the subclavian vasculature and brachial plexus. These rare masses typically cause pain and functional deficits from their invasive nature. Their location may be confused with lesions found at the apex. Hydatid disease may be located in any organ or tissue outside of the liver and lungs. The apical location of hydatid cysts outside of these primary sites are seldom.

\section{CASE}

A 36-year-old greengrocer presented with the complaints of cough, dyspnea, and occasional pain in his right shoulder on exertion. The physical examination revealed no abnormalities. Laboratory tests were unremarkable. A chest $x$-ray revealed a $4 \times 3 \mathrm{~cm}$ mass on the apical portion of the right lung (Figure 1).

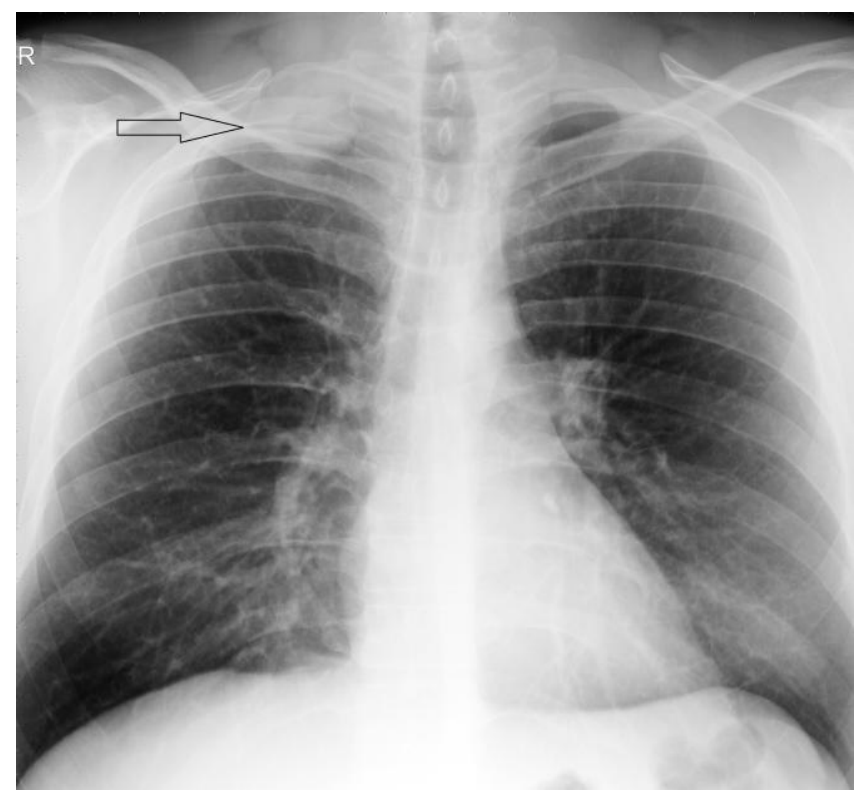

Figure 1. Chest $x$-ray showing the opacity with the first right rib.

Computerized tomography (CT) scans were suggestive of an extraparenchymal and well defined $42 \times 33 \mathrm{~mm}$ lesion in the first right rib. The mass was observed to cause destruction and expansion of the rib. The lesion seemed to produce pressure on the lung. Its proximity to the brachial plexus was typical of shoulder pain. No mediastinal lymph node enlargement was observed (Figure 2.a, b, c, Figure 3.a, b). The ultrasound of the abdomen was clear. Findings from the flexible bronchoscopy were unremarkable. The patient underwent video assisted thoracoscopy for excision and diagnosis of the extra-pulmonary mass. An infected $4 \times 4 \mathrm{~cm}$ cystic mass was seen in the first costa upon exploration. The frozen section report was inconclusive for a malign lesion. The surrounding tissues were thoroughly assessed to rule out any other diseases. The perioperative cystic appearance of the lesion led to the suspicion of an infected hydatid cyst. The resection of the involved rib was performed via thoracotomy. The final pathological study confirmed hydatid disease. The patient was discharged without morbidity.

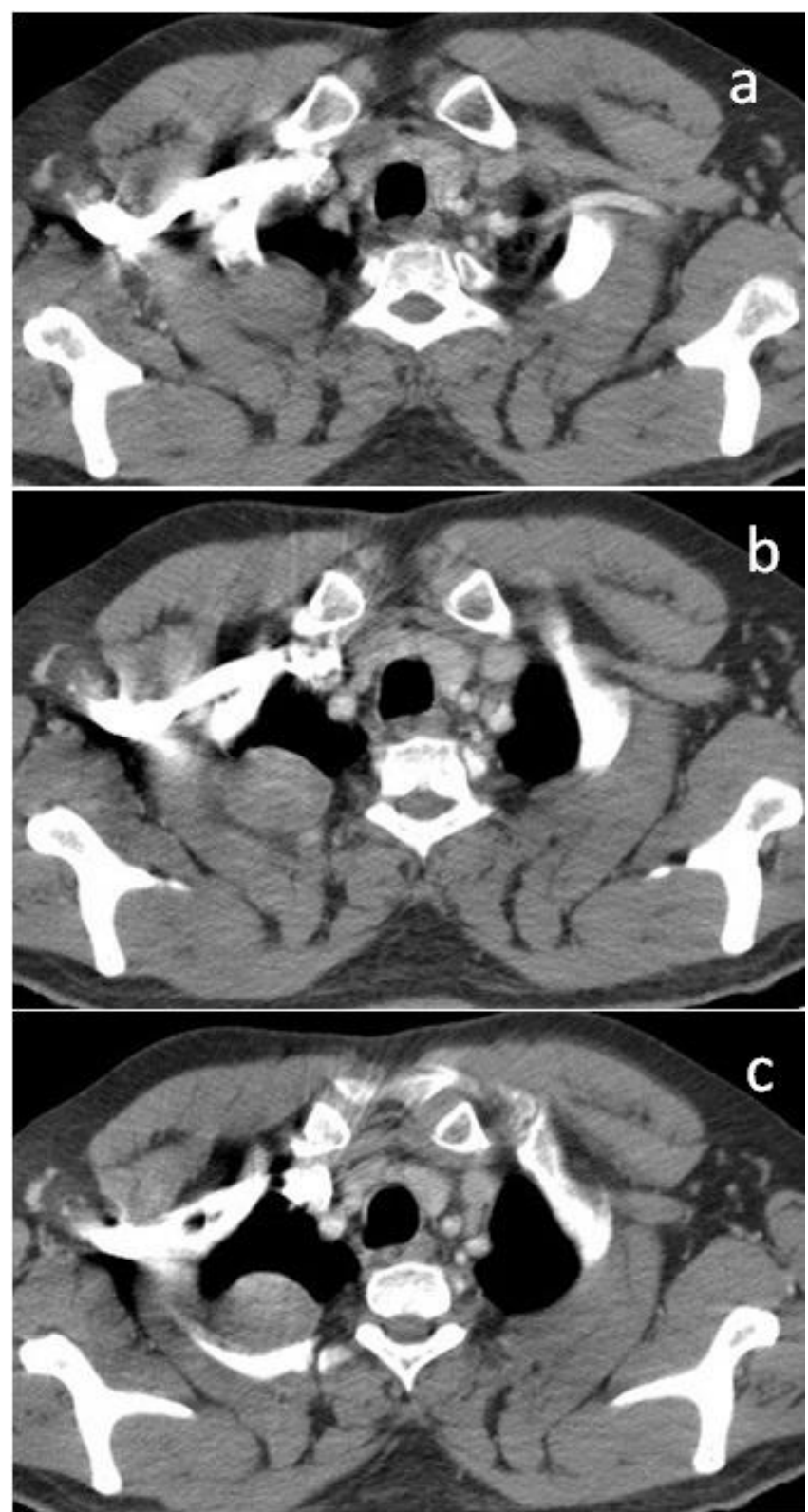

Figure $2 a, b, c$. CT scans of the chest showing a tumoral lesion of the rib extending to adjacent pleural cavity and lung.

\section{DISCUSSION}

Superior sulcus tumors typically arise in the apex of the lung and may invade the near ribs, the brachial plexus, the subclavian vessels, the stellate ganglion, and adjacent vertebral bodies. They include lung cancers, metastatic solid tumors, and unusual presentations of hematological malignancies, infectious diseases, cervical ribs and pulmonary nodules. Superior sulcus tumors are peripherally 
located and characterized by a spicular density in the apices of the lung, with or without mediastinal abnormality.

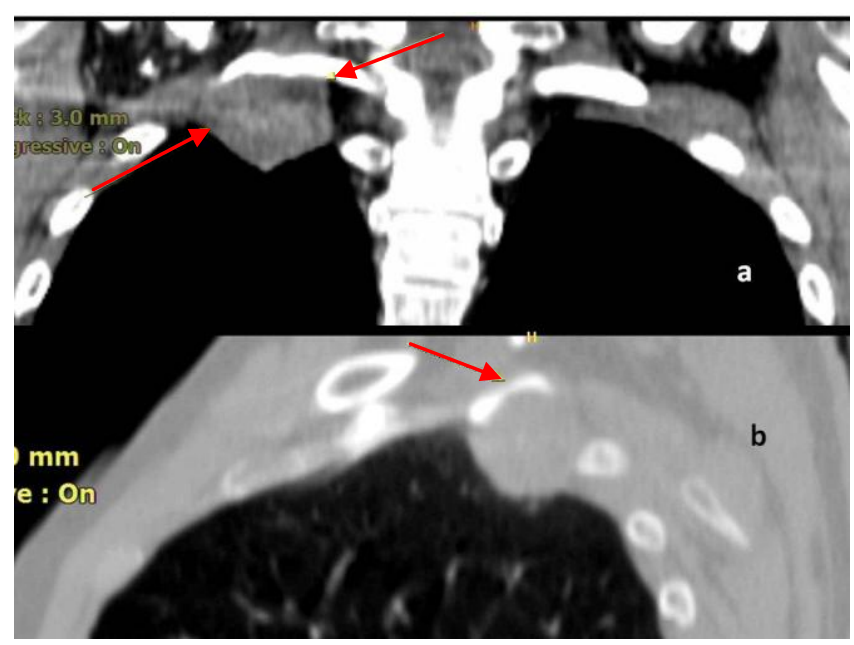

Figure $3 a, b$. Axial and coronal scans of the lesion causing anterolateral displacement of the surrounding.

Hydatid disease is a parasitic infestation caused by echinococci. Humans consume echinococcal eggs via contaminated water and food, or contact with dogs. The liver and lungs are the primary sites, though they may locate in any organ or tissue outside of the liver and lungs. Embryos escaping the lungs may be seen in the epicardium, myocardium, pleural space, spleen, kidney, peritonea, brain, and bones. In the above case, the hydatid cyst is primary; it involved neither the lung nor the liver. It is known that hydatid cysts occur in different anatomic locations. A hydatid cyst, particularly of the rib, is a very rare disease (1). A rare presentation of extra-pulmonary, intrathoracic and intraosseous hydatid cavitary lesion may lead to misdiagnosis. As seen in the current case, an intrathoracic extra-pulmonary hydatid cyst lies in the region of the bone structures, can cause bone destruction, and mimics superior sulcus tumors.

Hydatid cysts located on the chest wall are rarely observed. The ribs, sternum, or soft tissues of the chest wall are potential locations. Involvement of bones in hydatid disease is $0.9-2 \%$. This rate is $50-70 \%$ in liver, $11-17 \%$ in the lungs, $2.4-5.3 \%$ in the soft tissues, $0.5-3 \%$ in the heart, $5 \%$ in pericardium, $0.5-4.7 \%$ in the muscles and subcutaneous tissue. Location in the bones, particularly in the costae, is very rare $(2,3)$.

Diagnosis of intraosseous hydatid cysts is difficult because they do not have pathognomonic radiological findings.
Typical manifestations of the disease may be absent in osseous hydatids. They may appear as cortical destruction in the bones (4). The rigid structure of the bones intra-osseously limits the enlargement of cysts so they insidiously grow. When the cortical integrity of the bone breaks down, the cyst causes evident findings as it expands into the adjacent tissue and exerts pressure. Malign fibrous histiocytoma, chondrosarcoma, myeloma, metastatic tumors, aneurysmal osseous cysts, and tuberculosis should be considered in differential diagnosis $(5,6)$.

A tumoral lesion oriented in the first rib or superior sulcus tumor was suspected in the patient, since he had no imaging evidence of hydatid disease elsewhere. In endemic areas, hydatid cysts may be encountered in any anatomical locations outside the liver and lungs. Hydatid disease is very unusual in developed countries, but possible in immigrant communities. It is important that hydatid cysts should be considered in the differential diagnosis of the superior sulcus or mediastinal tumors in cases in doubt. The gold standard is wide excision of the rib, and an excellent outcome depends on the careful protection of the vicinity.

\section{CONFLICTS OF INTEREST}

None declared.

\section{REFERENCES}

1. Al- Qudah A. Primary echinococcosis of the first rib. Asian Cardiovasc Thorac Ann 2000; 8: 62-3.

2. Karaoglanoglu N, Gorguner M, Eroglu A. Hydatid disease of the rib. Ann Thorac Surg 2001; $71: 372-3$. [CrossRef]

3. Demir HA, Demir S, Emir S, Kacar A, Tiryaki T. Primary hydatid cyst of the rib mimicking chest wall tumor: a case report. J Ped Surg 2010; 45: 2247-9. [CrossRef]

4. Rao S, Parikh S, Kerr R. Echinococcal infestation of the spine in North America. Clin Orthop Relat Res 1991; 271: 164-9. [CrossRef]

5. Agarwal S, Shah A, Kadhi SK, Rooney RJ. Hydatid bone disease of the pelvis. A report of two cases and review of the literature. Clin Orthop Relat Res 1992; 280: $251-5$. [CrossRef]

6. Levy Faber D, Best LA, Militianu D, Ben Nun A. Thoracic outlet syndrome caused by hydatid cyst of the first rib-rare but important. Indian J Surg 2010; 72: 485-7. [CrossRef] 